\title{
Marta Czyżak
}

Biblioteka Uniwersytecka w Toruniu, Uniwersytet Mikołaja Kopernika w Toruniu University Library in Toruń, Nicolaus Copernicus University in Toruń Universitätsbibliothek Toruń, Nikolaus Kopernikus Universität in Toruń e-mail: Marta.Czyzak@bu.uni.torun.pl

\section{igitalizacja najcenniejszych}

\section{średniowiecznych rękopisów Biblioteki}

\section{Uniwersyteckiej w Toruniu. „Sermones} super Psalterium"Jana de Abbatisvilla z 2. połowy XIII w. (Rps 9/I). Problemy związane $z$ identyfikacją tekstu

W ciągu ostatnich dwóch lat w Bibliotece Uniwersyteckiej w Toruniu zrealizowano, dzięki wsparciu Ministerstwa Kultury i Dziedzictwa Narodowego, dwa projekty badawczo-konserwatorsko-digitalizacyjne obejmujące rękopisy średniowieczne znajdujące się w zbiorach biblioteki. Pierwszy z nich, zatytułowany: „Digitalizacja najcenniejszych rękopisów”, zakładał konserwację zachowawczą, digitalizację i udostępnienie w Kujawsko-Pomorskiej Bibliotece Cyfrowej 19 rękopisów, należących do polsko-niemieckiego dziedzictwa kulturowego (2013 r.) ${ }^{1}$. Drugi koncentrował się na jednym z liczącej 72 rękopisy kolekcji: trzynastowiecznym komentarzu do psalmów o nieustalonych na początku prac autorstwie i pochodzeniu (proweniencji). Jego celem było opracowanie naukowe, pełna konserwacja i digitalizacja obiektu (2014 r. $)^{2}$.

Wszystkie zdigitalizowane rękopisy pochodzą z dawnej Państwowej i Uniwersyteckiej Biblioteki w Królewcu. Na początku 1944 r. najcenniejsze rękopisy i stare druki biblioteki ewakuowano na zamek w Bałdze (niem. Balga, obecnie obwód kaliningradzki) oraz do majątków rodziny zu Dohna w Karwinach (niem. Karwinen) i Słobitach (niem. Schlobitten) koło Pasłęka ${ }^{3}$. Te dwie ostatnie miejscowości, zgodnie z ustaleniami konferencji w Jałcie, znalazły się w granicach

\footnotetext{
Dostępne w World Wide Web: http://www.bu.umk.pl/rekopisy-online; M. Czyżak, Digitalizacja najcenniejszych średniowiecznych rękopisów Biblioteki UMK, Biuletyn EBIB [online], 2014, nr 2 (147) [dostęp 3 III 2015]. Dostępny w World Wide Web: http://open.ebib.pl/ojs/index.php/ebib/article/view/225.

2 Biblioteka Uniwersytecka w Toruniu (dalej: BUT), sygn. Rps 9/l. Dostępny w World Wide Web: http://kpbc.umk.pl/ dlibra/docmetadata?id=91323\&from=publication.

3 M. Komorowski, Das Schicksal der Staats- und Universitätsbibliothek Königsberg, Bibliothek Forschung und Praxis, R. 4: 1980, nr 2, s. 139-140, 144-150; R. G. Päsler, Zum Handschriftenbestand - speziell dem mittelalterlichen deutschsprachigen - der ehem. SUB Königsberg, [w:] Kulturgeschichte Ostpreußens in der Frühen Neuzeit, hrsg. von K. Garber, M. Komorowski, A. E. Walter, Tübingen 2001, s. 119-128.
} 
państwa polskiego. Odnalezione cymelia zostały zabezpieczone (jako mienie opuszczone) przez Inspektorat Szkolny w Pasłęku, a następnie w lipcu 1946 r. przekazane (na podstawie zezwolenia Kuratorium Okręgu Mazurskiego) dr. Stefanowi Burhardtowi, ówczesnemu dyrektorowi Biblioteki Uniwersyteckiej w Toruniu, kierującemu akcją pozyskiwania dla biblioteki zbiorów zabezpieczonych ${ }^{4}$.

Wspomniany komentarz do psalmów (Rps 9/l) - który będzie głównym przedmiotem niniejszego studium - w czasie przemieszczeń wojennych stracił górną okładzinę $z$ wpisaną na wewnętrznej stronie notą proweniencyjną.

Rękopis został spisany w jednej kolumnie przez kilku pisarzy - co skutkuje zmiennymi wymiarami lustra tekstu $(12,5-13 \mathrm{~cm} \times 8-8,5 \mathrm{~cm})$, który dodatkowo wędruje na stronie (charakteryzuje się zmiennym oddaleniem kolumny tekstu od marginesów $)^{5}$. Cechy pisma - tekstury - wskazują na powstanie rękopisu w 2 . połowie XIII w.

Rubrykacje zostały wykonane czerwonym atramentem (przypuszczalnie minią ołowiową), kilkoma rękami, najprawdopodobniej później niż sam tekst (w 2. poł. XIV w.?). Przy poszczególnych komentarzach wpisano tytuły, zachęcające czytelnika do zagłębienia się w lekturę, w rodzaju: Sequitur supra supra nakaschube („następuje to, co wcześniej, powyżej nakaschube [?]”) - do Ps 23, 5: Hic accipiet benedictionem a Domino (k. 37v) - il. 1; sequitur ulterius et magis, verte folia („następuje więcej i lepiej, odwróć kartę”) - do Ps 30, 17: Illustra faciem tuam (k. 61v); seqitur capetulum hic et inde („następuje rozdział tu i stąd”) - do Ps 30, 24: Retribuet Dominus facientibus superbiam (k. 63r); sequitur satur supra satur („następuje obfitość nad obfitością" [?]) - do Ps 39, 3: Statuit supra petram pedes meos (k. 90v); sequitur Margaritam [?] („następuje perła”) - do Ps 39, 10: Annuntiavi iustitiam tuam (k. 92r); Sequitur gestam prestam („następuje lepsze dzieło” [?]) - do Ps 40, 4: Dominus opem ferat illi (k. 93r); Sequitur mazabec [?] - do Ps 51, 3: Quid gloriaris in malitia (k. 113r).

Pod tekstem nieznany autor rubrykacji dopisał czerwonym atramentem: Sequitur nil magis nihil plus sed finis. Nasza braczcza jara dissza supra supra supra nakaschube („następuje nic więcej, nic dalej, tylko koniec”). Nie wiemy, co znaczą kolejne słowa: Nasza braczcza jara dissza...

Komentowane wersety psalmów rozpoczynają, wpisane także czerwonym atramentem, kaligraficzne inicjały (lombardy), o wysokości 1-2 wersów, wśród nich cztery z delikatną dekoracją roślinną wychodzącą na margines (k. 18v, 20r,

\footnotetext{
4 Archiwum BUT, sygn. 1/240, Sprawozdania dr. S. Burhardta z podróży służbowych (lipiec 1946-lipiec 1947), s. 7; BUT, Rps 1099/III, S. Burhardt, Historia Biblioteki Głównej UMK w Toruniu (za lata 1945-1949); idem, Historia pierwszego pięciolecia Biblioteki UMK, Studia o Działalności i Zbiorach Biblioteki Uniwersytetu Mikołaja Kopernika, cz. III, Toruń 1987, s. 13-15, 20-21; H. Baranowski, Zbiory Biblioteki Uniwersyteckiej w Toruniu, ich rozwój i kierunki przyszłego kształtowania, ibidem, cz. V, Toruń 1990, s. 23-31. O ochronie zbiorów zabezpieczonych w Polsce zob. R. Nowicki, Działalność Aleksandra Birkenmajera na rzecz ochrony zbiorów bibliotecznych: ziemie zachodniej i północnej Polski w latach 1945-1947, Poznań 2006; idem, Powojenna ochrona zbiorów bibliotecznych w Polsce w latach 1944-1955: wybór źródeł, Bydgoszcz 2013, s. 11-17, s. 30: Ustawa z dnia 6 maja 1945 r. o majątkach opuszczonych i porzuconych.

5 Na k. 182r-213v marginesy wewnętrzne liczą $4 \mathrm{~cm}$, zewnętrzne $-1 \mathrm{~cm}$, zob. B. Wojdyła, L. Bannach-Szewczyk, Dokumentacja konserwatorska XIII-wiecznego kodeksu pergaminowego Tractatus super Psalterium, Rps 9/I, ze zbiorów Biblioteki Uniwersyteckiej w Toruniu, Toruń 2014 (wydruk komputerowy przechowywany w Sekcji Rękopisów BUT).
} 
24r, 37v) oraz liczne z pogrubionymi laskami liter i krótkimi wypustkami (np. k. 48v, 50v, 55v, 92r, 111r, 144v). Rubrykacje tekstu uzupełniają znaki akapitu (paragrafy), zakreślające $w$ tekście także cytaty biblijne oraz pionowe kreseczki sygnalizujące początek zdania.

Na marginesach kart kodeksu umieszczono 25 rysunków: dwa zostały wykonane atramentem żelazowo-galusowym (k. 144v: św. Małgorzata na smoku, dzik; k. 207r: studium twarzy Chrystusa) - il. 2, pozostałe skreślono ołowianym rysikiem (postaci Chrystusa, świętych, motywy heraldyczne). Wzornik rysunków pochodzi z połowy XIV w. (k. 204r: Chrystus z księgą, k. 207r: studium twarzy Chrystusa) lub z lat 70.-80. XIV w. (k. 144v: św. Małgorzata na smoku, k. 167r: Chrystus zmartwychwstały, k. 190r: św. Katarzyna, k. 205r: studium głowy kobie(cej) $)^{6}$.

Z późniejszej, XVI-wiecznej (?) oprawy rękopisu zachowały się jedynie grzbiet i dolna okładzina: deska dębowa obciągnięta brunatną skórą cielęcą, ozdobioną ślepymi tłoczeniami wykonanymi strychulcem, składającymi się z podwójnej ramki wypełnionej ornamentem plecionkowym. Na wyklejce okładziny umieszczono drzeworytowy ekslibris księcia Albrechta Hohenzollerna (1490-1568) - znak przynależności rękopisu do otwartej w 1540 r. dla publiczności książęcej biblioteki zamkowej w Królewcu?.

Zgodnie z notą proweniencyjną, która znajdowała się niegdyś na wewnętrznej stronie górnej okładziny (obecnie zaginionej), w 2. poł. XV w. rękopis należał do Michaela Blumenaua, wikariusza katedry w Królewcu ${ }^{8}$. W 1483 r. duchowny ten ofiarował kodeks klasztorowi augustianów-eremitów w Patollen w dobrach Groß Waldeck, w komornictwie Domnau, około $40 \mathrm{~km}$ na południe od Królewca (obecnie Ossokino, rejon Bagrationowsk, obwód kaliningradzki). Klasztor już w 1524 r. został opuszczony przez zakonników, a w styczniu 1526 r. opuszczone budynki i dobra książę Albrecht Hohenzollern przekazał swemu doradcy, póź-

6 B. Pietrulewicz, Zespół szkiców zawartych w średniowiecznym rękopisie 9/l ze zbiorów BUT. Praca seminaryjna na kierunku Ochrona Dóbr Kultury, specjalność Zabytkoznawstwo i Historia Dzieł Sztuki, Toruń 2011 (mps w zbiorach Sekcji Rękopisów BUT); M. Jakubek-Raczkowska, Opis zdobień Rps 9/I do Katalogu rękopisów średniowiecznych Biblioteki Uniwersyteckiej w Toruniu, Toruń 2011 (mps w zbiorach Sekcji Rękopisów BUT).

7 J. Tondel, Ekslibrisy Biblioteki Zamkowej księcia Albrechta, [w:] J. Tondel, Książka w dawnym Królewcu Pruskim, Toruń 2001, s. 266, s. 275 il. (wariant III ekslibrisu). Na odwrociu widoczny fragment większego ekslibrisu księcia Albrechta (wariant II. 4), J. Tondel, op. cit., s. 274 (il.); por. A. Warda, Die exlibris des Herzogs Albrecht von Preussen, [w:] Königsberger Beiträge. Festgabe zur vierhundertjährigen Jubelfeier der Staats- und Universitätsbibliothek zu Königsberg Pr., hrsg. von C. Diesch, Königsberg 1929, s. 353.

8 Zob. H. Eysenblätter, Die Klöster des Augustiner Eremiten im Nordosten Deutschlands (Neumark, Pommern, Preussen), Altpreussische Monatsschrift, Bd. 35: 1898, s. 387. Autor nazywa Michaela Blumenau oficjałem sambijskim: „Nach der Inschrift auf der inneren Seite des Deckels ist das Buch von dem samländischen Offizial Michael Blumenu dem Convente „versus Patollen” 1483 geschenkt”; powtarza tę informację E. J. Guttzeit, Das Kloster Pattolen (zur Heiligen Dreifaltigkeit) innerhalb der Geschichte des Rittergutes Gros Waldeck, Kreis Pr. Eyleau, [w:] Studien zur Geschichte des Preussenlandes, hrsg. von E. Bahr, Marburg 1963, s. 201.

Michael Blumenau - oficjał sprawia jednak problemy identyfikacyjne. Znani są natomiast Nicolaus Blumenau kanonik i oficjał sambijski 1448, 1468, dziekan kapituły sambijskiej 1464, 1465, biskup-elekt pomezański 1464-1466 , ostatni raz wspomniany w 1468 r. oraz Michael Blumenau - student uniwersytetu w Rostoku w 1466 r. (R. Biskup, Das Domkapitel von Samland (1285-1525), Toruń 2007, s. 456-459, zwł. przyp. 2840, 2848), być może tożsamy z późniejszym wikariuszem katedry sambijskiej. Wydaje się bowiem, że należy przyjąć odczyt E. Kuhnerta i przypisać Michaelowi funkcję wikariusza katedry w Królewcu (R. G. Päsler, Zur Herkunft von Handschriften und alten Druken der ehemaligen Staats- und Universitätsbibliothek Königsberg. Ernst Kuhnerts Provenienzregister, Berichte und Forschungen. Jahrbuch des Bundesinstituts für ostdeutsche Kultur und Geschichte, Bd. 3: 1995, s. 47: Michael Blumenau vicarius ecclesiae Sambiensis. 
niejszemu ochmistrzowi dworu swojej małżonki Doroty (1527 r.), Heinrichowi von Kittlitz w nagrodę za wierną służbę 9 .

Księgozbiór klasztorny, podobnie jak inne księgozbiory z zsekularyzowanych konwentów krzyżackich i klasztornych, książę Albrecht - mecenas uczonych, założyciel biblioteki zamkowej, przewiózł najprawdopodobniej bezpośrednio do Królewca ${ }^{10}$.

Tutaj rękopis otrzymał wspomniany ekslibris, a w końcu XVI w. - sygnaturę odnotowaną w spisie inwentarzowym Martina Sylvestra Grabego starszego z 2. poł. XVII w.: „Xx 141”, umieszczoną także na grzbiecie kodeksu'11 W Królewcu: najpierw w bibliotece zamkowej, potem w Bibliotece Królewskiej - od 1918 r. Państwowej - i Uniwersyteckiej, rękopis pozostawał do II wojny światowej.

\section{Robertus Bacon OP, Tractatus super Psalterium?}

Pozbawiony tytułu tekst zapisany na kartach rękopisu sprawiał problemy identyfikacyjne. Wyniki poszukiwania incipitu utworu w Repertorium biblicum F. Stegmüllera nasunęły przypuszczenie, że w naszych zbiorach znalazł się jeden z nielicznych znanych egzemplarzy komentarza do Księgi Psalmów autorstwa Roberta Bacona, mistrza sztuk uniwersytetu paryskiego (1219), pierwszego dominikanina - wykładowcy teologii w uniwersytecie oksfordzkim (1234-1238), zmarłego tamże w 1248 r. ${ }^{12}$

Jego Tractatus super Psalterium zachował się tylko w dwóch egzemplarzach $^{13}$. Zbieżność z incipitami komentarzy do psalmów Bacona podanymi w Repertorium biblicum (łącznie 5 incipitów i explicit tekstu) wykazują incipit toruńskiego utworu, incipity komentarzy do wersetów psalmów 2, 1 i 18, 13 oraz końcowa część explicitu. Inne są już jednak komentarze do wersetów Ps 32, 12 i Ps 50, 3.

Incipit i explicit obu tekstów oraz rozbieżne pierwsze zdania komentarzy do wersetów Ps 32, 12 i 50, 3 ukazują dwie poniższe tabele.

9 H. Eysenblätter, op. cit., s. 387-391 (s. 390: miejsce nosi obecni nazwę Groß Waldeck, potocznie „das Kloster”, nazwa Patollen została zapomniana); E. J. Guttzeit, op. cit., s. 206-207.

10 J. Tondel, Biblioteka zamkowa (1529-1568) księcia Albrechta Pruskiego w Królewcu, Toruń 1992, s. 86-87.

11 B. Jähnig, Katalog der Handschriften der landesherrlichen Bibliothek in Königsberg 1700/1720, [w:] Königsberger Buch- und Bibliotheksgeschichte, hrsg. von A. E. Walter, Köln 2004, s. 271: „Xx 141: In Psalterium commentarius”.

12 B. Smalley, Robert Bacon and the early Dominican school at Oxford, Transactions of the Royal Historical Society, IV series, vol. 30: 1948, s. 1-2, 8; W. P. Eckert, Robert Bacon, [w:] Lexikon des Mittelalters (dalej: LMA), Bd. 1-9, Stuttgart 1999, Bd. 7, kol. 900-901; idem, [w:] Lexikon für Theologie und Kirche (dalej: LThK), Bd. 1-14, Freiburg 1986, Bd. 8, kol. 1336; Robertus Bacon OP [w:] Alcuin. Infothek der Scholastik [online], [dostęp 20 V 2015], dostępny w World Wide Web: http://www-app.uni-regensburg.de/Fakultaeten/PKGG/Philosophie/Gesch_Phil/ alcuin/philosopher.php?id=1951.

13 F. Stegmüller, Repertorium biblicum medii aevi, Bd. 1-11, Matriti 1940-1980 (dalej: RB), Bd. 5, nr 7363 [online], [dostęp 20 V 2015], dostępne w World Wide Web: http://www.repbib.uni-trier.de/cgi-bin/rebilndex.tcl. Wspomniane dwa rękopisy to: Olmütz, Kapitel 171; Oxford, Bodleian Library, SC 2764 (Bodl. 745), 2. poł. XIII w., k. 193-497. 
Tabela 1. Zbieżności w tekście incipitu i explicitu rękopisu 9/I i skrótu komentarza R. Bacona w Repertorium biblicum

\begin{tabular}{|c|c|}
\hline Rps 9/I & RB \\
\hline $\begin{array}{l}\text { k. 1r: Beatus vir, qui non abiit in consilio im- } \\
\text { piorum etc. - Iste martyr vel confessor est } \\
\text { beatus vir, qui non abiit in consilio impiorum } \\
\text { mundi, carnis et diaboli. Mundus consulit } \\
\text { temporalia acquirere. Caro carnales deli- } \\
\text { cias... a facie terre viventie. }\end{array}$ & $\begin{array}{l}\mathrm{nr} 7363 \text { (Robertus Bacon): Beatus vir (Ps } \\
1,1) . \text { - Hoc exponitur de uno martyre vel } \\
\text { confessore sic: In consilio impiorum. Id est } \\
\text { mundi, carnis et diaboli. Mundus enim con- } \\
\text { sulit temporalia... terrae viventium. }\end{array}$ \\
\hline $\begin{array}{l}\text { k. 302r: in septimo verbo quasi in VII corda } \\
\text { ineffabilis dilectionis est argumentum. Pater } \\
\text { in manus tuas commendo spiritum meum. }\end{array}$ & $\begin{array}{l}\mathrm{nr} 7363 \text { Expl: cum dixit (Luc 23, 46): Pater, } \\
\text { in manus tuas commendo spiritum meum } \\
\text { etc. Ipsi gloria in saecula saeculorum. } \\
\text { Amen. }\end{array}$ \\
\hline
\end{tabular}

Tabela 2. Rozbieżności incipitów komentarzy do wersetów Ps 32, 12 i 50, 3

\begin{tabular}{|c|c|}
\hline Rps 9/I & RB \\
\hline $\begin{array}{l}\text { k. 69v: Beata gens... - Quae sit illa gens, } \\
\text { quae sit illa hereditas, quam Dominus elegit } \\
\text { ? Hoc est ordo clericalis et ipse Dominus } \\
\text { hereditas est eorum... }\end{array}$ & $\begin{array}{l}\text { nr } 7363 \text { (Robertus Bacon): Beata gens (Ps } \\
\text { 32, 12). - Quae sit illa gens, quae specia- } \\
\text { liter et antonomastice dicitur esse Domini, } \\
\text { satis claret. }\end{array}$ \\
\hline $\begin{array}{l}\text { k. 110v: Miserere mei, Deus... - Cum di- } \\
\text { vine fortitudo sic inextimabilis maxima eius } \\
\text { ostenditur misericordia, qua sola per ipsam } \\
\text { fortitudinem retinet... }\end{array}$ & $\begin{array}{l}\text { Miserere (Ps } 50,3) \text { - Beatus Bernardus } \\
\text { super hunc versum ita: Sicut sunt peccata } \\
\text { nostra minima, et sicut et mediocra sunt et } \\
\text { magna, sic est misericordia parva, medio- } \\
\text { cris et magna. }\end{array}$ \\
\hline
\end{tabular}

\section{Joannes Halgrinus de Abbatisvilla, Sermones super Psalterium}

Dopiero porównanie fragmentów komentarzy Roberta Bacona cytowanych przez Beryl Smalley z rękopisu Bodleian Library 745 (jedyny znany rękopis podający imię autora traktatu) ${ }^{14} \mathrm{z}$ odpowiednimi fragmentami toruńskiego utworu pozwoliło stwierdzić, że ten drugi rękopis zawiera jednak nie komentarze angielskiego dominikanina, ale wskazywane przez autorkę jako pierwowzór pracy Bacona, komentarze do psalmów (sermones super psalterium) paryskiego teologa Joannesa Halgrinusa de Abbatisvilla. Ten ostatni do ok. 1216 r. wykładał teologię w Uniwersytecie Paryskim, w 1216 r. objął funkcję dziekana kapituły w Amiens, w 1225 r. został arcybiskupem Besançon, w 1227 r. kardynałem - biskupem San-

\footnotetext{
${ }_{14}$ Oxford, Bodleian Library, SC 2764 (Bodl. 745), k. 193-497: Tractatus fratris R(oberti) Bacun super Psalterium, zob. B. Smalley, op. cit., s. 8-15.
} 
ta Sabina (1227-1237). W latach 1227-1229 pełnił funkcję legata papieskiego w Hiszpanii i Portugali. Zmarł w 1237 r. $^{15}$

Jan de Abbatisvilla komentował psalmy - odsłaniał ich literalny i duchowy (tj. moralny i alegoryczny) sens w Uniwersytecie Paryskim, przygotowując w ten sposób studentów do głoszenia kazań. Bacon był najprawdopodobniej uczniem Jana w Paryżu ok. 1210 r., sporządził z jego wykładu własny skrypt, nazwany przez B. Smalley czwartą reportatio (przekazem) wykładów Jana de Abbatisvilla ${ }^{16}$. Wzorem mistrza komentował później (przed 1234 r.) psalmy w Oksfordzie: jego własny Tractatus super Psalterium (znany z rękopisu Bodleian Library 745), oparty w dużej mierze na notatkach z wykładów paryskich, wykazuje dużą zależność od komentarzy mistrza ${ }^{17}-z$ drugiej strony (co podkreśla B. Smalley) Bacon był samodzielnym autorem: stosował porzuconą przez mistrzów paryskich na początku XIII w. formę pytań teologicznych: quaestiones w swym tradycyjnym, niewyspecjalizowanym jeszcze wykładzie (egzegezie) Pisma św., odwoływał się imiennie do Arystotelesa ${ }^{18}$. Język jego kazań jest bardziej potoczny, a satyra bardziej wyostrzona (w czym według autorki ujawnia się ich dominikański i angielski charakter). Aktualizował nauczanie moralne Jana de Abbatisvilla, wskazując na przewinienia konkretnych grup społecznych w Anglii'19, przede wszystkim duchownych, przyjmujących liczne msze św. anniwersarzowe dla zysku, śpiewających msze św. tylko po to, by przypodobać się kobietom, sprawujących liturgię niezgodnie z normą kościoła katedralnego. W komentarzu do wersetu Ps 33, 14: Prohibe linguam... konkretyzował ogólną krytykę paryskiego mistrza skierowaną przeciw beztrosko, bluźnierczo przysięgającym na Boga, przywołując przykład rybałtów ${ }^{20}$.

Znamy 24 rękopisy z komentarzami Jana de Abbatisvilla, przy czym różnią się one między sobą - są to najprawdopodobniej studenckie reportatio - notatki, skrypty popularnego wśród studentów wykładowcy paryskiego, jest wśród nich być może oficjalna wersja wykładu, zaaprobowana przez mistrza ${ }^{21}$. Jeden z nich: rękopis z biblioteki bolońskiej bazyliki św. Petroniusza (Bologna, Ms. S. Petronio 87) został wydany dwukrotnie jako dzieło św. Antoniego z Padwy (Bologna 1757,

15 C. Eubel, Hierarchia catholica medii aevii sive Summorum pontificum, S. R. E. cardinalium, ecclesiarum antistitum series: e documentis tabularii praesertim Vaticani collecta, digesta, edita, t. 1, Ab Anno 1198 usque ad Annum 1431 perducta, Patavii 1960 (reprint oryginału: Monasterii 1913), s. 6, 38, 137; RB, Bd. 3, nr 4541; B. Smalley, op. cit., s. 4-5; Iohannes Halgrinus, [w:] Alcuin. Infothek der Scholastik [online], [dostęp 24 II 2015], dostępny w World Wide Web: http://www-app.uni-regensburg.de/Fakultaeten/PKGG/Philosophie/Gesch_Phil/ alcuin/philosopher. php?id=3199.

16 B. Smalley, op. cit., s. 7-8.

17 Ibidem, s. 5: „Bacon's indebtedness to John of Abbeville leaps to the eye [...]. If we set them [kolekcje kazań obu autorów] side by side we have a clear case of the master-pupil relationship".

18 Ibidem, s. 12-16.

19 Ibidem, s. 8: „Bacon has enlivened his source by reproducing it in more colloquial terms. He has made the satire more pointed, and he likes to illustrate his doctrine by giving concrete examples".

20 Ibidem, s. 9-10, por. Rps 9/I, k. 72v: Ita qui iurat per Dominum reverantiam exhibet Deo in quantum iurat, scilicet ignominiose et [...] iurando Deum blasphemat.

${ }^{21} \mathrm{RB}, \mathrm{Bd} .3$, nr 4541 (wcześniejsza literatura). Repertorium nie wymienia naszego rękopisu. O studenckich reportationes w XII i XIII w. zob. B. Smalley, The study of the Bible in the Middle Ages, Notre Dame 1989, s. 200-207 . 
Paris 1880)22. Właśnie ta edycja została wykorzystana przez Johannesa Baptistę Schneyera w jego Repertorium kazań średniowiecznych - już ze wskazaniem właściwego autora ${ }^{23}$. Rękopis ten (a także dwie wspomniane edycje i skrót w Repertorium Schneyera) zawiera 277 komentarzy (dwa pierwsze tylko w formie krótkich dyspozycji), w tym 14 komentarzy do fragmentów, które nie są komentowane w toruńskim tekście. Z kolei nasz rękopis zawiera 272 komentarze, w tym osiem nowych, do wersetów niekomentowanych w rękopisie bolońskim.

Różnice między przekazami obu rękopisów (toruńskiego i bolońskiego) występują w obrębie pierwszych komentarzy, do wersetu 16, 10 włącznie: do tego miejsca Księgi Psalmów nasz rękopis pomija 13 komentarzy - zawiera za to sześć innych, nowych (Ps 2, 1; 4, 1; 7, 13; 7, 15; 13, 3; 15, 7). Kolejne nowe komentarze dotyczą wersetów 24, 10 i 26, 10, brakuje natomiast komentarza do wersetu 93, 20.

Oba teksty komentują najpierw wersety 1, 1 i 1, 2 (choć incipit komentarzy jest już różny! $)^{24}$, a następnie odchodzą od siebie aż do komentarza do wersetu 5, 5: Mane astabo et videbo (k. 3v). Toruński rękopis podaje przed nim dwa komentarze, do wersetów Ps 2, 1 i 4, 1, boloński pięć - do innych wersetów! Ten ostatni zawiera dalej dwa nowe komentarze, których brak w toruńskiej kolekcji, następnie oba rękopisy komentują wspólnie werset Turbatus est a furore (Ps 6, 8). Po nim następują komentarze do dwóch innych wersetów, a następnie komentarz do wspólnego wersetu: Domine, Dominus noster (Ps 8, 2). Kolejne komentarze dotyczą już niemal tych samych wersetów z podanymi wcześniej wyjątkami.

Pierwsze zdania komentarzy toruńskiego przekazu w blisko 150 przypadkach są identyczne lub prawie identyczne z incipitami bolońskiego rękopisu, w pozostałych ponad 110 przypadkach wyrażają zazwyczaj tę samą myśl, jednak w inny sposób, niekiedy trafniej, obszerniej, co nasuwa przypuszczenie, że mamy do czynienia z inną reportatio - innym skryptem, notatkami z tego samego wykładu mistrza. Ścisłe określenie relacji, zależności obu dostępnych wersji tekstu wymagałoby dalszych, pogłębionych badań. Poniższa tabela porównuje jedynie wybrane, zbliżone incipity obu rękopisów.

\footnotetext{
22 Azzoguidius Polentonius, Sancti Antonii Ulissiponensis cognomento Patavini, Sermones in Psalmos ex autographo nunc primum in lucem editi, Bologna 1757 [online], [dostęp 19 VI 2015], dostępny w World Wide Web: http://www.europeana.eu/portal/record/9200110/BibliographicResource_1000126627386.html); C. A. Horoy, Medii Aevi Bibliotheca Patristica, Series I, t. 6, Paris 1880, kol. 575-1266; por. A. Callebaut OFM, Les sermons sur les psaumes imprimés sous le nom de s. Antoine, restitués au cardinal Jean d'Abbéville, Archivum franciscanum historicum, 25: 1932, s. 161-174 (zidentyfikował komentarz w rękopisie bolońskim jako dzieło Jana de Abbatisvilla).

23 J. B. Schneyer, Repertorium der lateinischen Sermones des Mittelalters für die Zeit von 1150-1350, Bd. 1-11, Münster 1969-1990 (dalej: Schneyer, Repertorium), Bd. 3, s. 539-558, nr 396-672.

24 Incipity komentarzy do dwóch pierwszych wersetów psalmu 1 (w rękopisie bolońskim podanych w formie krótkiej dyspozycji) z rękopisu 14804 Biblioteki Narodowej w Paryżu, zawierającego ten sam przekaz (reportatio) tekstu, podaje A. Callebaut, op. cit., s. 163: Beatus vir (Ps 1, 1). Psalmus iste agens de bono cantatur in festo alicuius martyris...
} 
Tabela 3. Porównanie wybranych incipitów komentarzy z rękopisu 9/I i Ms. S. Petronio 87

\begin{tabular}{|c|c|}
\hline BUT, Rps 9/I & $\begin{array}{c}\text { Ms. S. Petronio 87, ed. Bologna 1757, } \\
\text { Paris } 1880=\text { Schneyer, Repertorium, } \\
\text { nr 396-672 }\end{array}$ \\
\hline $\begin{array}{l}\text { k. } 3 v \text {. - Mane astabo. De viro iusto exponi- } \\
\text { tur. Per mane tria notantur. Nativitas exore- } \\
\text { mus gratiae et mane eternitatis. In verbo } \\
\text { astabo tria: perseverantiam, rectitudinem, } \\
\text { et comparationem... }\end{array}$ & $\begin{array}{l}\text { 403. - Mane astabo tibi et videbo (Ps } 5 \text {, } \\
\text { 5). - Astare significat perseverantiam, op- } \\
\text { erationem et rectitudinem. Mane autem est } \\
\text { nostrae nativitatis initium... }\end{array}$ \\
\hline $\begin{array}{l}\text { k. } 13 r . \text { - Illumina oculos meos... Hic vox est } \\
\text { fidelis, qui petit a Domino illuminari. Aliter } \\
\text { notandum, quod Deus illuminavit cecum } \\
\text { natum de luto facto ex sputo et Thobiam } \\
\text { de felle piscis, Paulum per impositionem } \\
\text { manus Ananie, angelum Philadelphie per } \\
\text { collirium... }\end{array}$ & $\begin{array}{l}\text { 416. - Illumina oculos meos (Ps 12, 5). - } \\
\text { Aliter illuminatus est caecus evangelicus, } \\
\text { aliter Tobias, aliter Paulus, aliter angelus } \\
\text { Laodiceae... }\end{array}$ \\
\hline $\begin{array}{l}21 \mathrm{r} \text { - In circuitu eius tabernaculum eius. } \\
\text { Per tabernaculum intelligere ecclesiam mi- } \\
\text { litantem, in qua debemus Deo militare dum } \\
\text { peregrinamur in corpore contra eius adver- } \\
\text { sarios scilicet demones, debent eciam turbe } \\
\text { [?] militantes suo regi assistere... }\end{array}$ & $\begin{array}{l}\text { 423. - In circuitu eius tabernaculum eius } \\
\text { (Ps 17, 12). - Per tabernaculum ecclesia } \\
\text { militans intelligitur, in qua militantes suo regi } \\
\text { quasi in tabernaculo assistere debent... }\end{array}$ \\
\hline $\begin{array}{l}52 \mathrm{v} . \text { - Vox Domini super aquas - Nota } \\
\text { quod in principio creationis [?] facta est vox } \\
\text { Domini super aquas, ut scilicet aquas quae } \\
\text { erant super firmamentum divideret ab his } \\
\text { quae erant sub firmamento... }\end{array}$ & $\begin{array}{l}\text { 443. - Vox Domini super aquas (Ps } 28,3 \text { ). } \\
\text { - In primo rerum primordio creavit Deus fir- } \\
\text { mamentum, ut divideret aquas ab aquis... }\end{array}$ \\
\hline $\begin{array}{l}\text { 57r. - Mieserere mei Domine, quoniam tri- } \\
\text { bulor. - Psalmista in persona uniuscuiusque } \\
\text { nostrum in tribulacione petens misericor- } \\
\text { diam clamat ad Dominum dicens: miserere } \\
\text { mei Domine... }\end{array}$ & $\begin{array}{l}\text { 446. - Miserere mei Domine, quoniam tri- } \\
\text { bulor (Ps } 30,10) \text { - - Haec est vox ecclesiae } \\
\text { clamantis in persona cuiuslibet nostrum et } \\
\text { postulantis misericordiam... }\end{array}$ \\
\hline $\begin{array}{l}\text { 100v. - Vendidisti populum tuum... - Haec } \\
\text { est querimonia martirum, qui vendiderunt } \\
\text { sanguinem suum nec receperunt precium... }\end{array}$ & $\begin{array}{l}\text { 475. - Vendidisti populum tuum sine pretio } \\
\text { (Ps } 43,13) \text { - Vox est martyrum conqueren- } \\
\text { tium, quod venditi sunt et venditionis suae } \\
\text { pretium non receperunt... }\end{array}$ \\
\hline $\begin{array}{l}\text { k. 182r: - Buccinate in Neomenia tuba... } \\
\text { - Neos novum, mene luna, inde neomenia } \\
\text { lune innovatio, idem est quod mensis ini- } \\
\text { tium, quod est in incensionem lune bucci- } \\
\text { nate tuba... }\end{array}$ & $\begin{array}{l}\text { 549. - Buccinate in Neomenia tuba (Ps } 80 \text {, } \\
\text { 4). - Neomenia idem sonat quod nova luna: } \\
\text { Neos enim novum, menes hoc est initium } \\
\text { mensis... }\end{array}$ \\
\hline $\begin{array}{l}\text { k. } 187 \text { r. - Imple facies eorum ignominia... - } \\
\text { Optat hoc psalmista, ut facies peccatorum } \\
\text { repleantur ignominia, ut tempes sibi videt [!], } \\
\text { et aliis videantur... }\end{array}$ & $\begin{array}{l}\text { 553. - Imple facies eorum ignominia (Ps } 82, \\
\text { 17). - Hoc optat propheta, ut facies pecca- } \\
\text { torum impleantur ignominia, ut sibi et aliis } \\
\text { videantur ignominosi... }\end{array}$ \\
\hline
\end{tabular}


Tezę o dwóch różnych reportationes potwierdza także analiza explicitów komentarzy w obu rękopisach. W 102 przypadkach są one identyczne lub niemal identyczne, przy czym zbieżność ta jest większa w końcowej części toruńskiego tekstu (od k. 252r). W 85 przypadkach explicity toruńkiego rękopisu mają jednak inną postać: w kilku (ośmiu) stwierdzonych przypadkach komentarze w nim są po prostu o kilka zdań dłuższe niż bolońskie komentarze, np. w komentarzu do wersetu Tanquam sponsus dominus precedens (Ps 18,6) toruński tekst jest dłuższy o 2 linie (k. 27r); w komentarzu do wersetu Haec fecisti et tacui (Ps 49, 21) - o 6 linii (109v-110r), w komentarzu do wersetu Adversum me loquebantur (Ps 68, 13) - o 6 linii (k. 149rv), w komentarzu do wersetu Defecerunt oculi mei (Ps 118, 82) - o 7 linii (k. 249r). W pozostałych ponad 70 przypadkach explicity, podobnie jak incipity, są jedynie zbliżone do zdań kończących komentarze bolońskie: wyrażają tę samą myśl innymi słowami.

Spośród czterech reportacji - wersji komentarza Jana de Abbatisvilla do wersetu Ps 32, 5: Delictum meum cognitum tibi feci... („Grzech mój wyznałem Tobie...") $)^{25}$, nauczającego dobrej spowiedzi, analizowanych przez B. Smalley w ostatniej części artykułu²6, tekst w toruńskim rękopisie wykazuje największe podobieństwo do wersji zawartej w rękopisie z oksfordzkiej Bodleian Library (Ms. Bodley 727). Autorka datuje rękopis „przed połową XIII w.”, a tekst - krótszy niż w bolońskim rękopisie - uznaje za studenckie notatki ${ }^{27}$. W poniższej tabeli porównano tekst z Ms. 727 z odpowiednim fragmentem toruńskiego rękopisu. Podkreślono odmienne fragmenty.

\begin{tabular}{|c|c|}
\hline $\begin{array}{l}\text { Joannes Halgrinus de Abbatisvilla, } \\
\text { Sermones super Psalterium } \\
\text { Ms. Bodley } 727 \text {, k. } 35 \mathrm{v} \text { (za B. Smalley, } \\
\text { s. 18-19) }\end{array}$ & $\begin{array}{l}\text { Joannes Halgrinus de Abbatisvilla, } \\
\text { Sermones super Psalterium } \\
\text { BUT, Rps } 9 / \text {, k. } 65 \mathrm{r}\end{array}$ \\
\hline $\begin{array}{l}\ldots \text { Quomodo sit confitendum, ostenditur } \\
\text { lob, Vii, dicens: Quapropter non parcam ori } \\
\text { meo... (Jb } 7,11) \text {. }\end{array}$ & $\begin{array}{l}\text {... sequitur quomodo, quod ostenditur Job, } \\
\text { Vii, dicens: Non parcam ori meo... }\end{array}$ \\
\hline $\begin{array}{l}\text { Siquidem ori non parcit, qui peccatum non } \\
\text { palians, sicut est, illud dicit. Ut si furatus est, } \\
\text { dicit: sum latro. Non dicat, ut plerique fa- } \\
\text { ciunt: ego habui (aliena). Quia sic palliando } \\
\text { confiteri, non est vera confessio. }\end{array}$ & $\begin{array}{l}\text { Ori non parcit, qui paccatum non palians, si- } \\
\text { cut est, illud dicit. Ut si furatus est dicat latro } \\
\text { sum }{ }^{28} . \underline{\text { Quidam dicunt de alieno homini, sed }} \\
\text { non confitetur ita paliando. }\end{array}$ \\
\hline $\begin{array}{l}\text { Loquendum est in amaritudine, non iocan- } \\
\text { do, non ridendo. }\end{array}$ & $\begin{array}{l}n \text { est in amaritudine, non iocan- } \\
\text { rident de paccato suo. }\end{array}$ \\
\hline
\end{tabular}

\footnotetext{
${ }^{25}$ Schneyer, Repertorium, nr 449: Delictum meum cognitum tibi feci. - Hic ostenditur, quid debemus confiteri, quomodo, quando et quare...

${ }^{26}$ Wspomniane cztery reportacje zawierają rękopisy: 1. Bologna, Ms. S. Petronio 87; 2. Oxford, Ms. Bodley $727 ; 3$. Paris, Bibliothèque national, lat. 15571; 4. Oxford, Ms. Bodley 745: Robertus Bacon.

${ }^{27}$ B. Smalley, op. cit., s. 6.
} 


In cantico Ezechie: Ecce in pace amaritudo
mea amarissima (Is 38,17$)$. Vis pacem cum
Domino ? Oportet, quod confessio sit amara
pro peccato cogitationis, amarior pro pec-
cato delectationis, amarissima pro sequela
operis, et sic fit in tribulatione spiritus.
Confabulari debet peccator, i.e. frequenter
confiteri, sicut qui fecit aliquid egregium
opus [?] funditus circumloquitur ipsum fac-
$\underline{\text { tum. }}$

Czy fakt bliskości toruńskiego tekstu i przekazu z oksfordzkiego rękopisu może świadczyć o wspólnym pochodzeniu lub pokrewieństwie obu tekstów - trudno przesądzić na tym etapie badań. Jak pisała B. Smalley: „Klasyfikacja wszystkich zachowanych rękopisów, która mogłaby ujawnić znacznie więcej wariacji, odmian tekstu, byłaby dobrą okazją do oswojenia się badacza z problemem, jaki przynoszą rękopisy powstające w Uniwersytecie Paryskim w tym okresie"29. Toruński rękopis jest z pewnością jedną ze wspomnianych studenckich reportationes - krążących wersji uniwersyteckiego komentarza do psalmów Jana de Abbatisvilla.

\footnotetext{
${ }^{28}$ „Ust nie ujarzmia ten, kto nie ukrywając grzechu mówi tak jak jest. Jeśli kradnie, niech mówi: jestem łotrem...”.

${ }^{29}$ B. Smalley, op. cit., s. 7: „The task of classifying all the surviving manuscripts, which might well bring many more variations to light, would give an excellent opportunity for a research student to familiarize himself with the type of problem raised by works produced in the Paris schools at this period".
} 


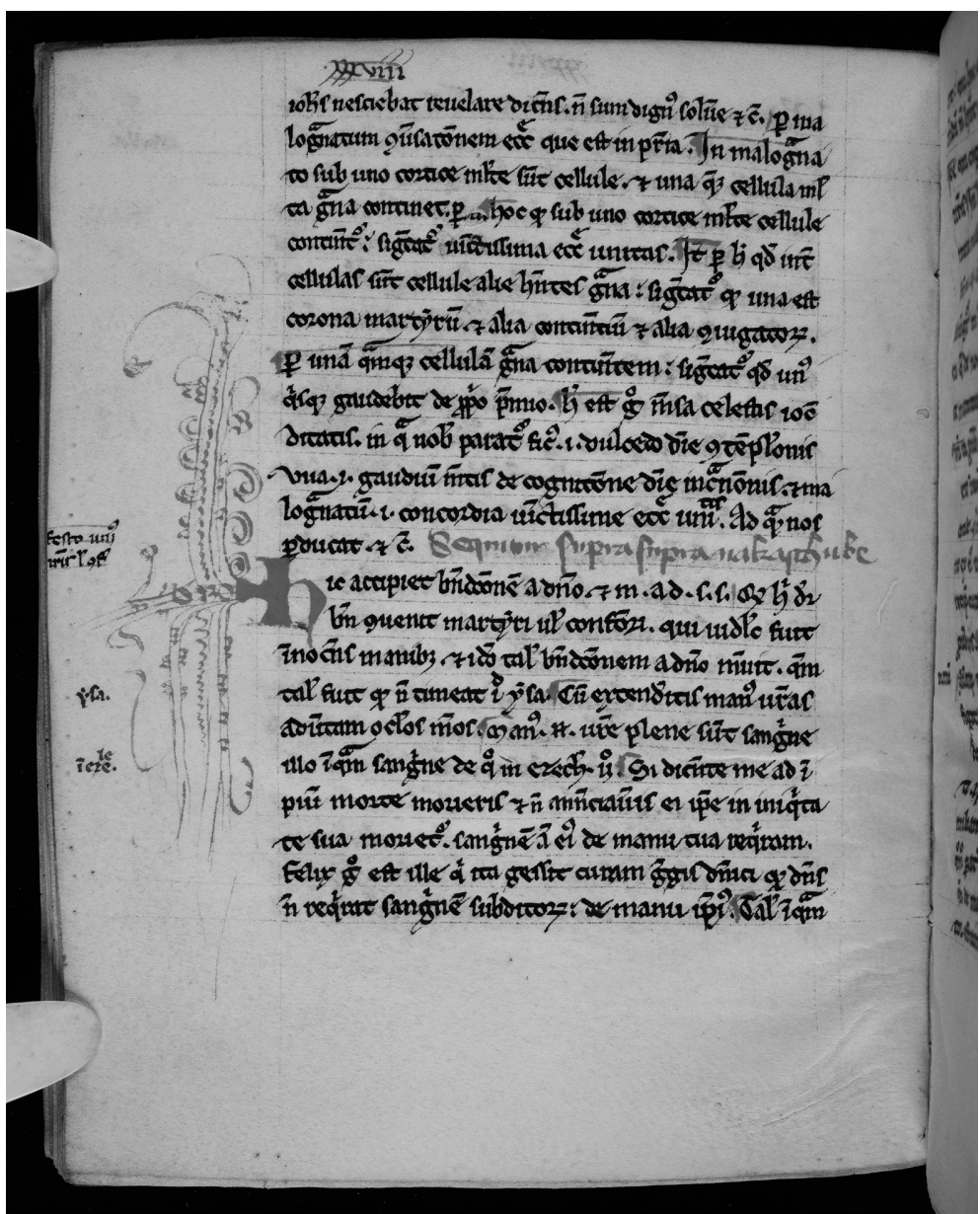

Ryc. 1. Joannes Halgrinus de Abbatisvilla, Sermones super Psalterium, BUT, Rps 9/I, k. 37v. Fot. P. Kurek 


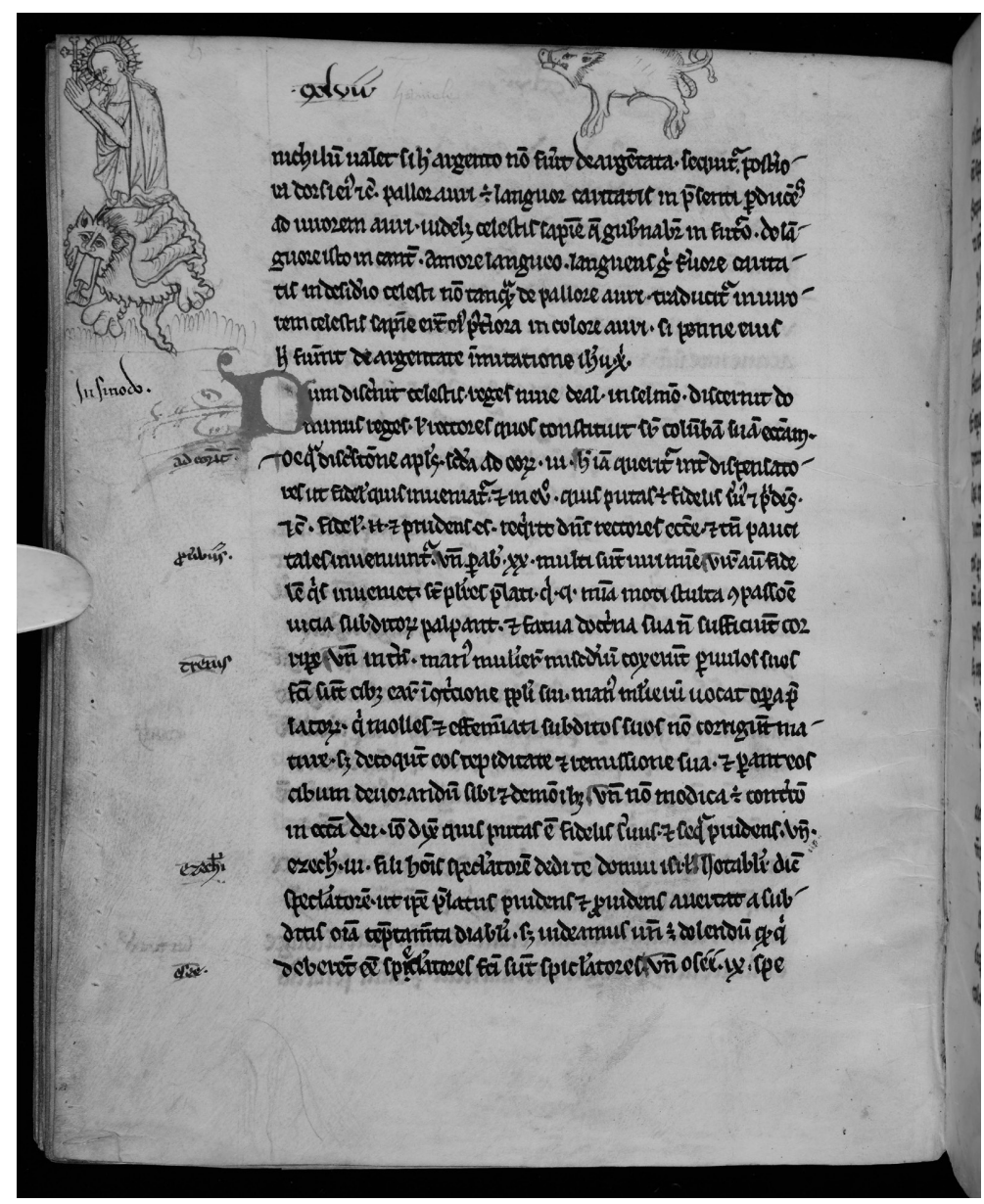

Ryc. 2. Joannes Halgrinus de Abbatisvilla, Sermones super Psalterium, BUT, Rps 9/I, k. 144v. Fot. P. Kurek 